\title{
PERANCANGAN SISTEM INFORMASI KOPERASI SYARIAH BERBASIS WEB
}

\author{
Riri Safitri, Anggi Kurniawati, Dody Haryadi \\ Teknik Informatika, Universitas Al Azhar Indonesia \\ Email: riri@uai.ac.id
}

\begin{abstract}
Jampang Village is one of the villages assisted by the Lembaga Amil Zakat Al Azhar Peduli Umat (LAZ APU) in the form of Kelompok Swadaya Masyarakat (KSM). The people in Jampang village have various jobs, including fish farmers, broiler breeders, doorman craftsmen, plant seed sellers and others. The Foundation provides funding or capital assistance to the community through a sharia microfinance institution that collects and distributes public funds in accordance with Islamic law. Koperasi Syariah Desa Jampang is currently still operating manually. Registration process, member information, amount of funds and reports are still done manually and stored in a notebook. This causes the operational process not to run properly, because the data is not organized and stored neatly. Based on the above conditions, a financial information system is designed that is a web-based Islamic cooperative, so that the operational processes and reports to members and administrators can run better and faster. Information systems are designed using SDLC through the stages of user requirements and analysis. With this method, it is expected that information systems are designed according to user needs.
\end{abstract}

Keywords: Information System, Web-Based System, Finance, Sharia Finance.

\begin{abstract}
ABSTRAK
Desa Jampang merupakan salah satu desa binaan Lembaga Amil Zakat Al Azhar Peduli Umat (LAZ APU) dalam bentuk Kelompok Swadaya Masyarakat (KSM). Masyarakat di desa Jampang memiliki beragam pekerjaan, diantaranya peternak ikan, peternak ayam potong, pengrajin keset, penjual bibit tanaman dan lainnya. Yayasan memberikan bantuan dana/modal kepada masyarakat melalui sebuah lembaga keuangan mikro syariah yang menghimpun dan menyalurkan dana mansyarakat yang sesuai dengan syariat Islam. Koperasi Syariah Desa Jampang saat ini masih melakukan operasi secara manual. Proses pendaftaran, informasi anggota, jumlah dana dan laporan masih dilakukan secara manual dan disimpan dalam buku. Hal ini menyebabkan proses operasional tidak berjalan dengan baik, karena datadata tidak teroganisir dan tersimpan dengan rapi. Berdasarkan kondisi di atas, peneliti membuat sebuah sistem informasi keuangan yaitu koperasi syariah berbasis web, sehingga proses operasional dan laporan kepada anggota dan pengurus dapat berjalan dengan lebih baik dan lebih cepat. Sistem informasi akan dibuat dengan menggunakan SDLC melalui tahapan user requirement dan analisis. Dengan metoda ini diharapkan sistem informasi yang dibuat sesuai dengan kebutuhan user. Penelitian yang dilakukan bertujuan untuk membuat sistem informasi keuangan untuk koperasi syariah berbasis web. Sistem yang dibuat dikhususkan untuk koperasi syariah di Desa Jampang Kabupaten Bogor.
\end{abstract}

Kata Kunci: Sistem Infomasi, Koperasi, Koperasi Syariah, Keuangan 


\section{PENDAHULUAN}

Koperasi Desa Jampang merupakan lembaga keuangan mikro syariah yang berlandaskan pada nilai-nilai Islam. Koperasi yang saat ini masih berbentuk Baitul Mal Tanwil (BMT) didirikan atas bantuan dari Lembaga Amil Zakat Al Azhar Peduli Umat (LAZ APU) pada tahun 2013 dalam program Sejuta Berdaya. Pengembangan BMT Desa Jampang akan ditingkatkan menjadi koperasi syariah dalam tahapan berikutnya.

BMT Desa Jampang menghimpun dana dari anggota dan menyalurkannya kepada masyarakat dalam bentuk pinjaman dan bantuan. Anggota BMT Desa Jampang terdiri dari masyarakat di sekitar BMT dalam satu kecamatan dengan tingkat ekonomi, pekerjaan dan penghasilan yang bervariasi. BMT membantu mansyarakat sekitar, khsususnya anggota BMT untuk dapat memberdayakan kemampuan yang mereka miliki untuk melakukan usaha sendiri berupa modal dan bantuan dana. BMT juga membantu anggota untuk menabung sebagian dari penghasilan mereka dan juga membantu masyarakat sekitar dengan program dana sosial.

Saat ini, BMT Desa Jampang masih beroperasi secara manual. Proses pendaftaran anggota dan Pencatatan data tabungan dan pinjaman anggota masih dilakukan secara manual dengan menuliskannya di dalam buku tulis. Laporan yang disampaikan kepada anggota dan LAZ APU sebagai pembina masih dalam bentuk laporan hardcopy dari buku tempat data dan informasi koperasi disimpan. Hal ini menyebabkan pelaksanaan operasional BMT tidak berjalan dengan baik, dikarenakan data yang dibutuhkan tersebar di beberapa buku yang berbeda.

Sebagai bahan acuan dan pertimbangan, peneliti melakukan study literature pada beberapa penelitian yang telah dilakukan sebelumnya. Dengan sistem informasi yang dibangun dapat mengelola data anggotadan transaksi sehinga laporan-laporan yang diperlukan ketua dapat dicetak berdasarkan periode tertentu agar dapat memudahkan dan mempercepat pengambilan keputusan [1].

\section{LANDASAN TEORI}

\subsection{Sistem Informasi}

Sistem informasi merupakan bagian dari suatu organisasi dengan gabungan orang, fasilitas, teknologi, media dan prosedur sebagai alur komunikasi. Sistem Informasi dapat menajdi media komunikasi dalam sebuah organisasi baik itu secara internal ataupun eksternal dengan penyebaran informasi [2].

Dalam suatu sistem informasi terdapat komponen-komponen yang mendukung terwujudnya sebuah sistem informasi. Beberapa komponen utama pendukung Sistem Informasi adalah perangkat keras (hardware), perangkat lunak (software), basisdata dan tentunya jaringan komputer. Sistem informasi memberikan kemudahan kepada penggunanya untuk mengkases dan mengelola data dan informasi yang tersimpan dalam system tersebut.

\subsection{Koperasi Syariah}

Koperasi berasal dari kata cooperation, dengan co mempunyai arti bersama dan operation mempunyai arti kerja, sehingga koperasi dapat diartikan sebagai kerja sama. Sedangkan secara terminologi, koperasi merupakan suatu perkumpulan atau organisasi yang beranggotakan badan hukum atau orangorang yang bekerja sama dengan penuh kesadaran untuk meningkatkan kesejahteraan anggota atas dasar sukarela secara kekeluargaan [3].

Koperasi di Indonesia telah dirumuskan secara lengkap dalam Undang-Undang. Fungsi dan peran koperasi menurut UU No.25 tahun 1992, adalah sebagai berikut; Fungsi dan peran Koperasi adalah [4]:

1. membangun dan mengembangkan potensi dan kemampuan ekonomi anggota pada khususnya dan masyarakat pada umumnya untuk meningkatkan kesejahteraan ekonomi dan sosialnya;

2. berperan serta secara aktif dalam upaya mempertinggi kualitas kehidupan manusia dan masyarakat;

3. memperkokoh perekonomian rakyat sebagai dasar kekuatan dan ketahanan perekonomian nasional dengan Koperasi sebagai sokogurunya;

4. berusaha untuk mewujudkan dan mengembangkan perekonomian nasional 
yang merupakan usaha bersama berdasar atas asas kekeluargaan dan demokrasi ekonomi.

Koperasi yang beroperasi dengan dasar syariah Islam atau yang dikenal dengan koperasi syariah memiliki konsep yang sama dengan koperasi pada umumnya. Perbedaannya terletak pada dasar atau landasannya, yang disesuaikan dengan akad dan ketentuan syariah Islam. Koperasi Simpan Pinjam dan Pembiayaan Syariah adalah koperasi yang kegiatan usahanya meliputi simpanan, pinjaman dan pembiayaan sesuai prinsip syariah, termasuk mengelola zakat, infaq/sedekah, dan wakaf [5].

Menurut keputusan nomor 90/Kep/M.KUKM/IX/2004 pengertian koperasi, KJKS dan UJKS adalah sebagai berikut; Koperasi adalah badan usaha yang beranggotakan orang-seorang atau badan hukum koperasi dengan melandaskan kegiatanya berdasarkan prisnsip koperasi sekaligus sebagai gerakan ekonomi rakyat yang berdasar atas kekeluargaan. Koperasi jasa keuangan syariah selanjutnya disebut KJKS adalah yang kegiatan usahanya bergerak di bidang pembiayaan, investasi dan simpanan sesuai pola bagi hasil (Syariah). Unit jasa keuangan syariah selanjutnya disebut UJKS adalah unit koperasi yang bergerak dibidang usaha pembiayaan investasi dan simpanan dengan pola bagi hasil (syariah) sebagai bagian dari kegiatan koperasi yang bersangkutan [6].

Lembaga Keuangan Syari'ah terdiri dari dua kelompok lembaga, yakni lembaga keuangan berbentuk bank dan lembaga keuangan berbentuk bukan bank, yaitu Unit Usaha Syari'ah dan Bait al Maal wa al Tamwil (BMT) [7]. BMT Secara harfiah/lughowi, Baitulmaal berarti rumah dana, dan baitul tamwil berarti rumah usaha. Baitulmaal lebih mengarah pada usaha-usaha pengumpulan dan penyaluran dana yang nonprofit seperti zakat, infak, dan sedekah. Sedangkan baitultamaal sebagai usaha pengumpulan dan penyaluran dana yang komersial [4].

Koperasi syariah membantu masyarakat yang ada di sekitar koperasi dalam hal pemberdayaan ekonomi. Dengan adanya koperasi syariah diharapkan anggota/ masyarakat di lingkungan koperasi, khususnya masyarakat dengan usaha mikro, kecil dan menengah untuk dapat meningkatkan dan mengembangkan kegiatan usahanya melalui program-program yang disediakan oleh koperasi syariah tersebut.

\subsection{Perancangan Sistem}

Unified Modeling Language (UML) merupakan suatu cara untuk memodelkan sebuah sistem perangkat lunak secara visual. UML (Unified Modelling Language) adalah suatu bahasa yang digunakan untuk menentukan, memvisualisaikan, membangun dan mendokumentasikan suatu sistem informasi.

Database merupakan sekumpulan data yang terpadu (interrelated data) yang dirancang terutama untuk meminimakan pengulangan data yang tersimpan secara bersama-sama dalam satu, sekaligus tempat sekumpulan berkas data yang terkomputerisasi. Pendefenisian database termasuk di dalamnya pengelompokkan tipe data, struktur dan konstrain dari data yang akan disimpan di dalam database. Pembangunan database merupakan proses penyimpanan data dalam media penyimpanan yang dikontrol oleh DBMS. Manipulalsi database termasuk di dalamnya fungi-fungsi seperti query database untuk mengambil data tertentu, update database dan membuat laporan dari data yang ada. Sharing database memungkinkan banyak user dan aplikasi untuk mengakses secara simultan.

\section{METODOLOGI}

\subsection{Metode Pengumpulan Data}

Proses perancangan sistem diawali dengan malakukan wawancara dan observasi ke lapangan, yaitu KSM Desa Jampang. Hasil wawancara dan observasi ke lapangan didapatkan data dan informasi berupa kondisi yang sedang berjalan, permasalahan dan kebutuhan sistem yang akan dibuat. Tahapan berikutnya adalah studi literatur dan membuat anlisis kebutuhan sistem yang akan dibuat. Proses perancangan sistem dibuat dengan menggunakan diagram UML. Perancangan selanjutnya adalah membuat mock-up sistem informasi.

\subsection{Analisa Sistem Berjalan}

Sistem yang saat ini ada pada koperasi KSM desa jampang masih dilakukan secara manual dan belum menggunakan teknologi informasi. Berikut adalah gambaran yang sedang berjalan di KSM desa Jampang : 
1. Calon Anggota datang ke koperasi untuk mendaftar menjadi anggota koperasi.

2. Calon Anggota mendapatkan informasi dari admin persyaratan untuk menjadi anggota dan persyaratan untuk melakukan pinjaman.

3. Jika formulir pendaftaran sudah diisi lengkap, admin menyalin data-data anggota tersebut.

4. Kemudian calon anggota membayar simpanan pokok sebesar Rp.50.000 ke bagian bendahara.

5. Bendahara menyerahkan buku simpanan kepada anggota.

6. Anggota yang melakukan transaksi simpanan atau penarikan simpanan langsung ke bendahara, kemudian bendahara mencatat transaksi di buku tabungan dan buku kas koperasi.
7. Anggota yang mengajukan pinjaman harus melengkapi persyaratan yang sudah diinformasikan.

8. Admin menyerahkan data pengajuan pinjaman anggota kepada tim survei.

9. Tim survei melakukan survei kerumah anggota.

10. Menyerahkan data hasil survei yang dilakukan oleh tim survei

11. Ketua koperasi mempertimbangkan pinjaman yang diajukan.

12. Admin konfirmasi persetujuan pinjaman dari ketua koperasi kepada bendahara

13. Bendahara menyerahkan pencairan dana pinjaman kepada anggota.

14. Anggota melakukan pinjaman mengangsur pengembalian pinjaman ke bendahara.

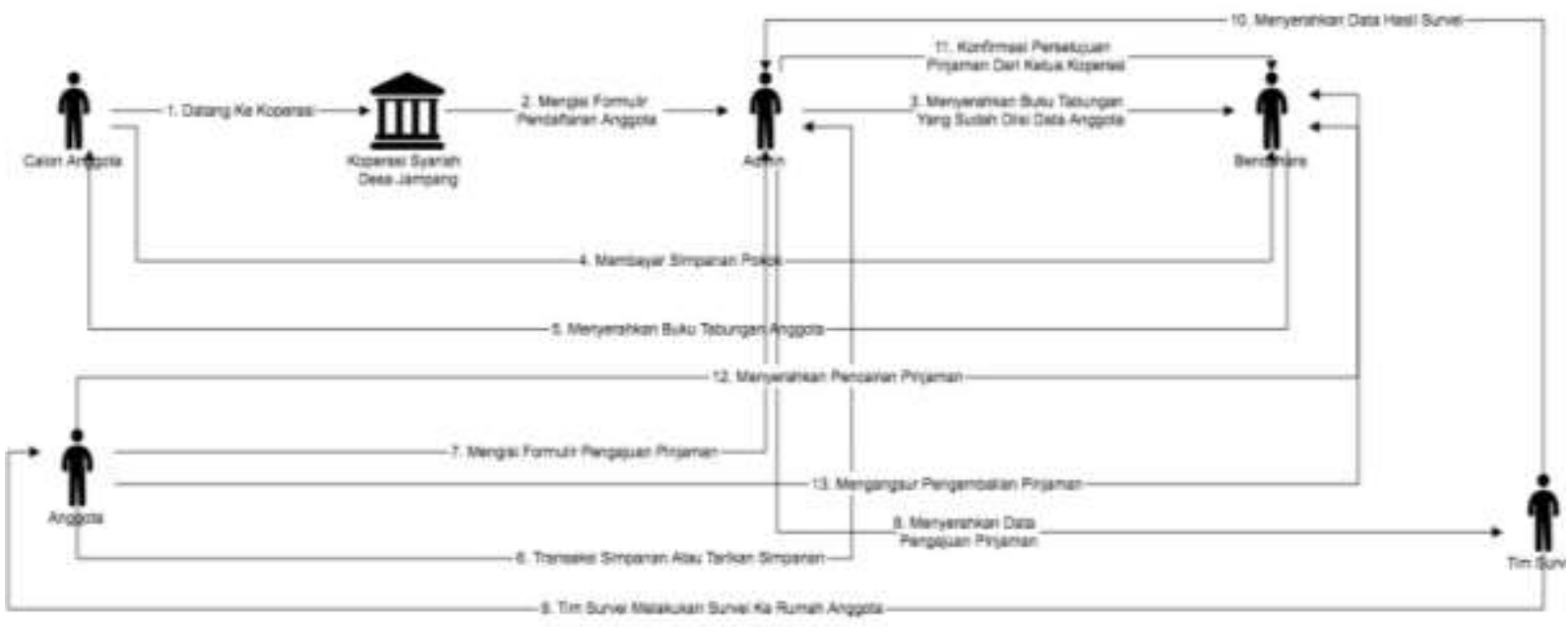

Gambar 1. Proses bisnis sistem koperasi Jampang

Berdasarkan analisis sistem terdapat permasalahan pada sistem yang ada sebelumnya yaitu berikut:

1. Sistem informasi KSM Jampang pada saat ini belum menggunakan bantuan teknologi informasi sehingga data-data tidak tersimpan dengan baik.

2. Pencatatan data pendaftaran anggota, penyimpanan, peminjaman pertemuan belum tercatat dengan baik sehingga mengakibatkan kesulitan dan lama dalam pengecekan data-data simpan pinjam pada koperasi.

3. Pembuatan laporan anggota, laporan penyimpanan, laporan peminjaman dibutuhkan waktu yang cukup lama karena masih menggunakan sistem seadanya.

\section{HASIL DAN PEMBAHASAN}

\subsection{Perancangan Sistem}

Perancangan sistem secara keseluruhan dibuat dengan diagram UML. Diagram yang digunakan diantaranya adalah Use case diagram dan Class Diagram.

\subsubsection{Use Case Diagram}

Use case diagram menjelaskan hubungan atau interaksi antara use case dan actor. Use case diagram sistem informasi yang akan dibangun dapat dilihat pada Gambar 2. 


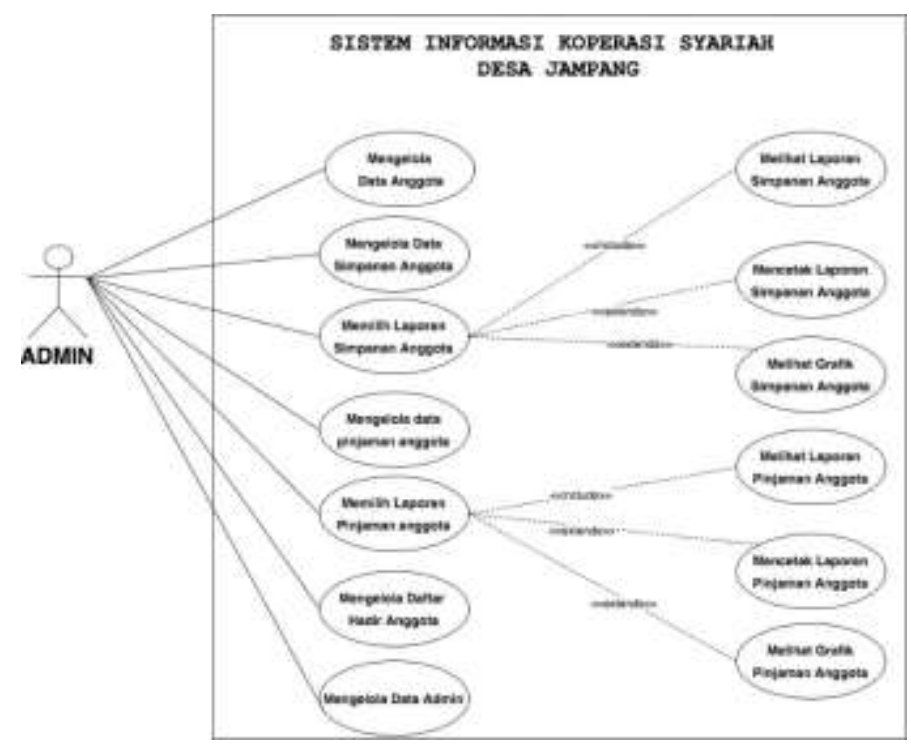

Gambar 2. Use case diagram

\subsubsection{Class Diagram}

Class Diagram menggambarkan struktur statis class di dalam sistem. Gambar 3 menunjukkan Class Diagram dari sistem yang akan dibangun

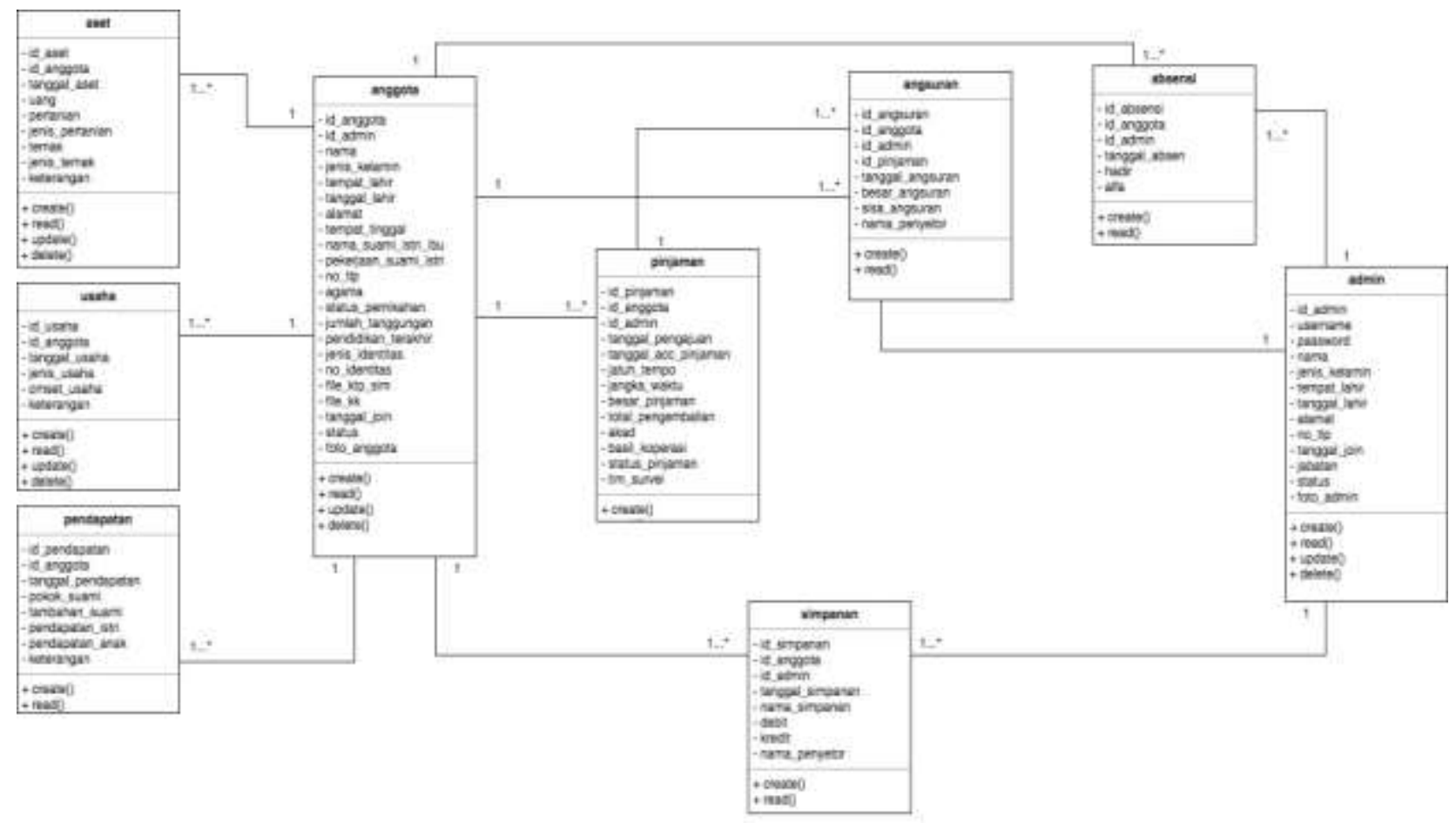

Gambar 3. Class diagram 


\subsection{Perancangan Database (ERD)}

Perancangan database sistem yang akan dibangun, dibuat dalam bentuk Entitiy Relationship Diagram (ERD). ERD adalah pemodelan data dalam diagram yang didasarkan pada data (entitas) di dunia nyata dan hubungan antara data [8]. ERD sistem dapat dilihat pada Gambar 4.

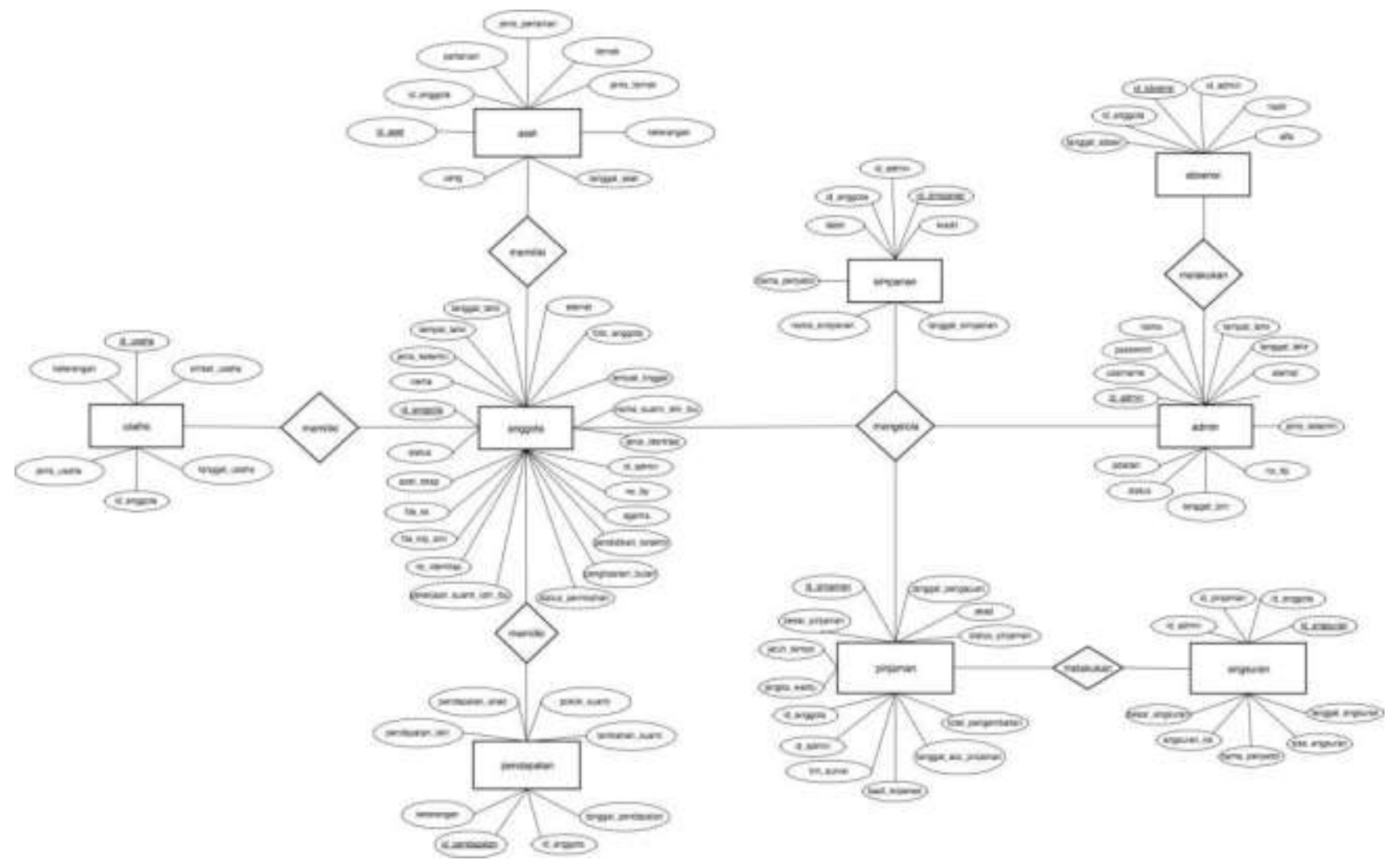

Gambar 4. Entity relationship diagram

\subsection{Perancangan Antar Muka}

Perancangan antar muka sistem yang akan dibangun didasarkan kepada hasil analisis sistem yang akan dibangun. Gambar 5 memperlihatkan struktur menu pada sistem informasi yang akan dibangun.

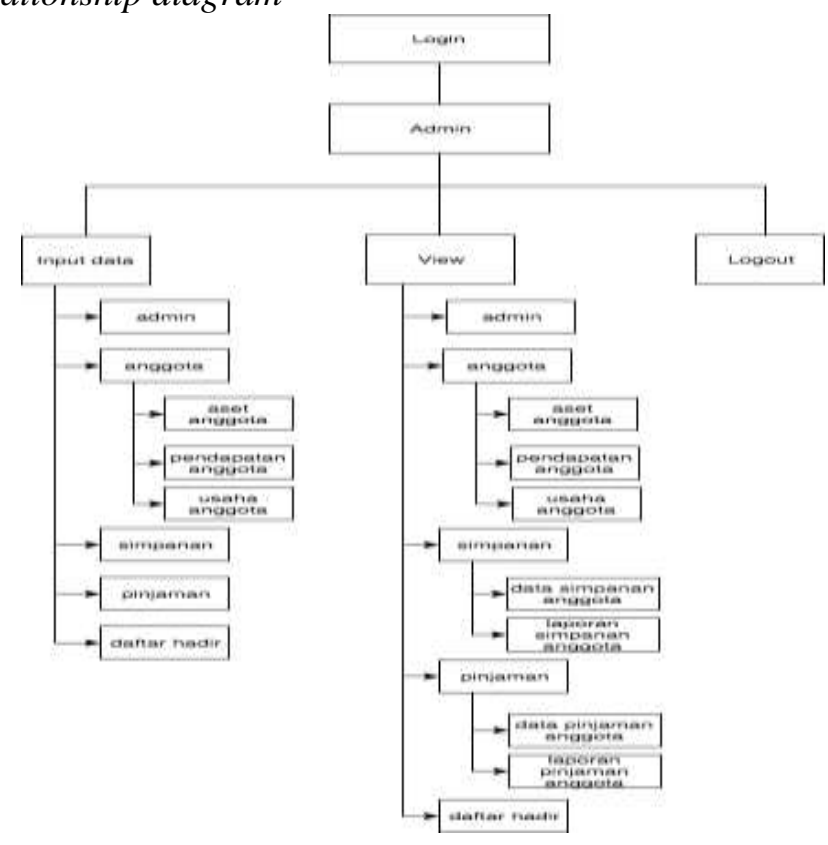

Gambar 5. Perancangan antar muka

Berikut adalah beberapa layout menu yang akan dibuat pada sistem informasi koperasi Desa Jampang. 


\section{Login Sistem}

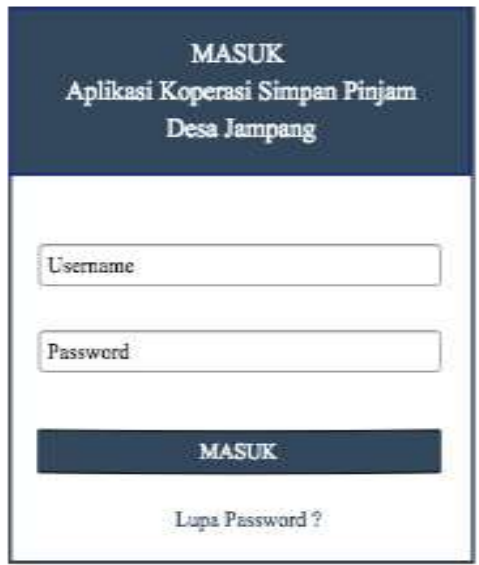

Gambar 6. Halaman login

\section{Layout Home}

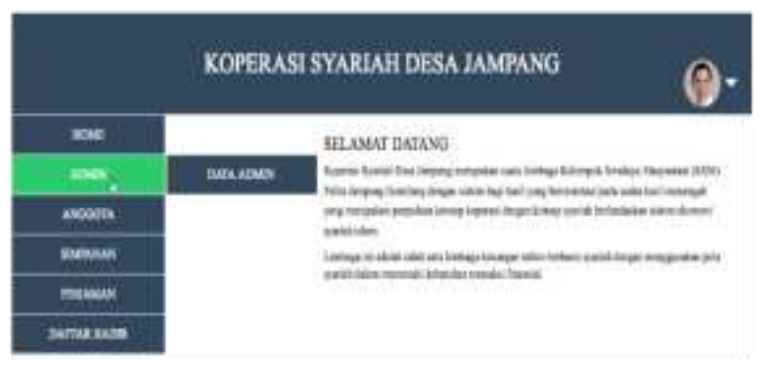

Gambar 7. Layout home

\section{Layout Data Admin}

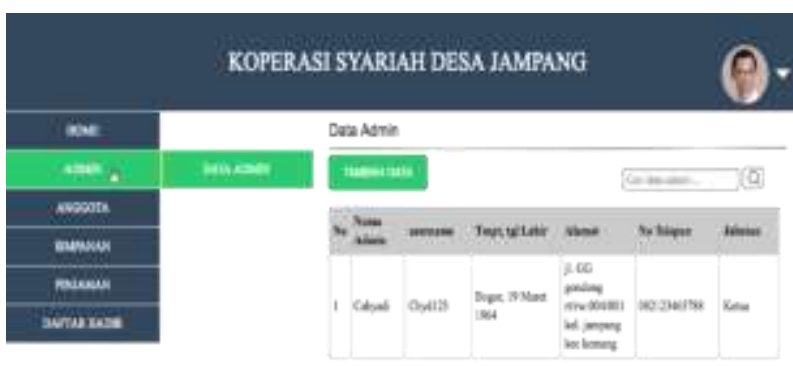

Gambar 8. Layout data admin
4. Layout Simpanan Anggota

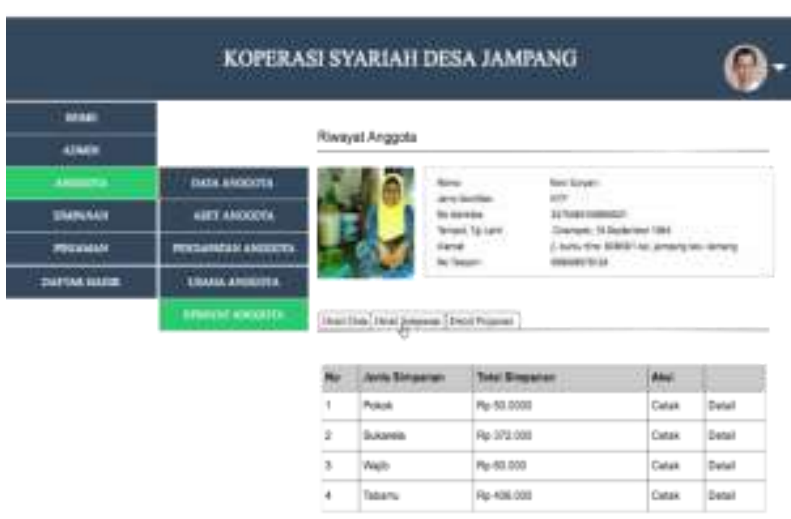

Gambar 9. Layout simpanan anggota

Sistem Informasi yang dibuat dirancang dengan menu laporan. Menu laporan ini merupakan laporan pinjaman dan simpanan anggota KSM setiap bulannya. Berdasarkan menu laporan ini nantinya, diharapkan pengurus KSM dapat melihat perkembangan ekonomi setiap anggota sehingga dapat dikelompokkan kepada beberapa kategori. Sistem ini juga dirancang untuk dapat membantu koperasi untuk memberikan layanan yang baik dan cepat kepada anggota. Hal Ini sesuai dengan manfaat Sistem Informasi dalam suatu perusahaan, yaitu menjadi lebih produktif, mendapatkan keunggulan kompetitif, menjangkau lebih banyak pelanggan dan meningkatkan layanan kepada pelanggan mereka [9].

\section{Layout laporan pinjaman}

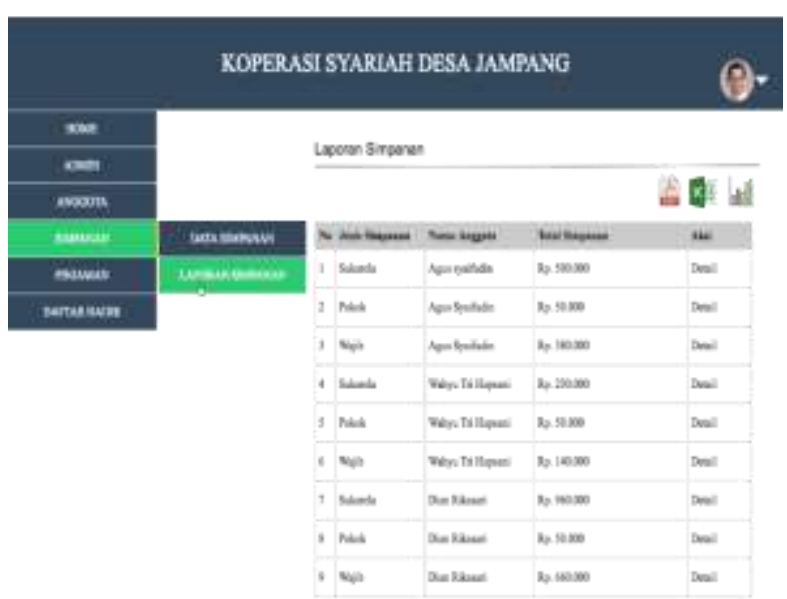

Gambar 10. Layout laporan pinjaman 


\section{Layout Angsuran Anggota}

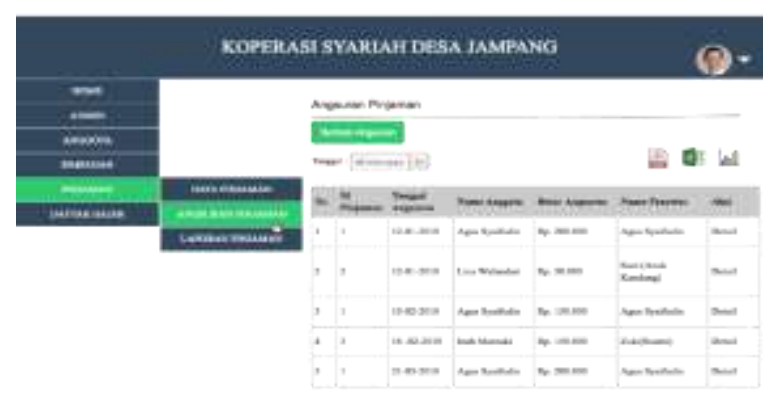

Gambar 11. Layout angsuran anggota

\section{KESIMPULAN}

Berdasarkan analisa dan perancangan dari Sistem Informasi Koperasi Syariah Desa Jampang maka dapat disimpulkan beberapa hal, yaitu dengan Sistem Informasi Koperasi Syariah Desa Jampang yang dibangun dapat mengelola data anggota dan transaksi sehingga laporan-laporan yang diperlukan ketua dapat dicetak berdasarkan periode tertentu agar memudahkan dan mempercepat mengambil suatu keputusan. Kemudian koperasi dapat mengetahui informasi simpanan maupun pinjaman dengan cara mengakses sistem ini. Selanjutnya, koperasi dapat melayani masyarakat dan anggota dalam menjalankan aktifitas simpan pinjam dengan baik, sehingga kepercayaan untuk melakukan simpan pinjam akan semakin meningkat.

Penelitian berikutnya adalah membuat implementasi sistem berdasarkan perancangan yang sudah ada.

\section{UCAPAN TERIMA KASIH}

Ucapan Terima Kasih kami sampaikan kepada RISTEKDIKTI atas bantuan dana penelitian dan publikasi yang telah diberikan dalam bentuk PDP (Penelitian Dosen Pemula).

\section{DAFTAR PUSTAKA}

[1] Izwan Afif, Rancang Bangun Sistem Informasi Simpan Pinjam Studi Kasus: Koperasi Simpan Pinjam Ittihadul Muhajirin, UIN Syarif Hidayatullah Jakarta, 2011.
[2] Jogiyanto, HM. 2001. Analisa dan Desain Sistem Informasi. Yogyakarta: Andi Offset.

[3] M. Ali Hasan, Berbagai Macam Transaksi Dalam Islam (Fiqh Muamalah), Jakarta: PT Raja Grafindo Persada, 2003, hlm. 161.

[4] Pasal 1 Undang-Undang No. 25 tahun 1992 tentang Perkoperasian.

[5] Keputusan Menteri Koperasi dan Usaha Kecil Menengah.2015

[6] Muhammad Sholahuddin dan Lukman Hakim, Lembaga Ekonomi dan Keuangan Syariah Kontemporer, Surakarta, Muhamadiyah University press, 2008. Hal. 179

[7] Hadin Nuryadin, BMT dan Bank Islam: Instrumen Lembaga Keuangan Syari'ah, Bandung: Pustaka Bani Quraisy, 2004, hlm. 159-160.

[8] Noor, Muhammad. Masykurinnisa, Ayu. 2017. Aplikasi Ayatul Ahkam Berbasis Web. Jurnal Sains dan Informatika Politeknik Negeri Tanah Laut, Volume 3, No. 2. Accessed from https://jsi.politala.ac.id/index.php/JSI/art icle/view/107/67 at Sept 2018

[9] Quizlet. 2018. Chapter 1: Managing in The Digital World MIS 304. Quizlet Inc. Accessed from https://quizlet.com/82784670/chapter-1managing-in-the-digital-world-mis-304flash-cards/ at November 2018. 